\title{
SPACE-TEMPORAL EVALUATION OF CHANGES IN TEMPERATURE AND SOIL USE AND COVER IN THE METROPOLITAN REGION OF BAIXADA SANTISTA
}

\author{
AVALIAÇÃO ESPAÇO-TEMPORAL DAS MUDANÇAS DO USO E COBERTURA DO \\ SOLO E TEMPERATURA NA REGIÃO METROPOLITANA DA BAIXADA SANTISTA
}

\section{Laurizio Emanuel Ribeiro ALVES'; Washington Luiz Félix CORREIA FILHO'; Heliofábio Barros GOMES'; José Francisco de OLIVEIRA-JÚNIOR'; Fabio de Oliveira SANCHES 2 ; Paulo Eduardo TEODORO}

1. Universidade Federal de Alagoas - UFAL, Maceió, AL, Brasil; 2. Universidade Federal de Juiz de Fora - UFJF, Juiz de Fora, MG, Brasil; 3. Universidade Federal de Mato Grosso do Sul - UFMS, Chapadão do Sul, MS, Brasil. eduteodoro@ hotmail.com

\begin{abstract}
The Metropolitan Region of Baixada Santista (MRBS) harbors one of the main port areas of Brazil: the Port of Santos. Due to the accelerated urban development in this region, the monitoring of biophysical parameters is fundamental. Therefore, this paper aims to i) estimate the soil surface temperature $\left(\mathrm{T}_{\mathrm{s}}\right.$ ) and identify the Urban Heat Islands (UHI) formation; and ii) compare the $\mathrm{T}_{\mathrm{s}}$ and the normalized difference vegetation index (NDVI) for MRBS from 1986 to 2016 using Landsat 5 and 8 images. Remote sensing tools are essential to meet the objectives of this work for providing both the spatial and temporal evaluation of a region. The spatial analysis was based on the NDVI to evaluate the vegetation density and size from five previously established classes (i.e., water bodies, urban grid, exposed soil and road corridors, shrub, and dense vegetation). The NDVI mapping showed a significant reduction in the cover area referred to the dense vegetation class $(91.7 \%)$, while the urban grid category increased by $29.4 \%$, resulting from the urban expansion and green cover reduction over the region during this period. Surface temperature thematic maps showed hightemperature values related to increased urbanization and decreased rainfall. Moreover, an $8^{\circ} \mathrm{C}$ rise in surface temperature over the last 30 years was registered due to the regional development, which has replaced natural soils by anthropic materials and reduced dense vegetation. This phenomenon has resulted in the formation and intensification of UHI, especially after the 2000s.
\end{abstract}

KEYWORDS: Vegetation index. Time series. Urban heat island.

\section{INTRODUCTION}

The coast of the southeastern region of Brazil is home to the major port area of the country, the Port of Santos. This region leveraged the development of the coastal zone and gave rise to the Metropolitan Region of Baixada Santista (MRBS). Given the degradation generated by the implantation of the port complex of Santos, the monitoring of the biophysical parameters in the region became fundamental due to the anthropic actions that alter the environment (CUNHA; OLIVEIRA, 2015).

Some technologies can assist the identification of patterns of changes in the regional climate, such as Remote Sensing (RS) (AGHAKOUCHAK et al., 2015; WILLIS, 2015; WU et al., 2015). The RS allows monitoring geographic and climatic changes occurring around the globe, whether at the spatial or temporal scales, or both. Moreover, its low cost enables its deployment in an operational way (BASTIAANSSEN, 2000; LOURENÇO; LANDIM,
2004; GOMES et al., 2009; ALVES et al., 2017). Remote sensors coupled to the orbital platforms can capture some changes in the terrestrial features, enabling the monitoring of specific areas, such as forest fires, desertification, urban, and dry expansion (QUEIROZ; GOMES, 2001; CAÚLA et al., 2016; CLEMENTE et al., 2017).

According to Schimdt \& Morrison (2012), the socio-environmental problems resulting from environmental degradation must be assessed more comprehensively and in depth, aiming at understanding the impacts that emerge between the ecosystem and society and how such interaction affects the climate. In this sense, the spatialtemporal mapping and the evaluation of urban areas, as performed by Barros and Lombardo (2016), indicate that the different constituents of soil use and occupation alter the thermal sensation of the region, especially in places occupied by industrial, commercial, and service activities.

These changes lead to a trend of more energy absorption and hence increase the 
temperature. However, places with a greater predominance of vegetation, such as parks and conservation units (CU), register a decreased air temperature (OLIVEIRA-JÚNIOR et al., 2015; GOULART et al., 2015; CLEMENTE et al., 2017). Nevertheless, the growth of regions with a high degree of urbanization, such as MRBS, must be measured aiming to improve and update the planning and mitigation of the region.

Among the several methods used to diagnose soil use and soil cover, the best known and applied is the Normalized Difference Vegetation Index (NDVI) (LOURENÇO; LANDIN, 2004; FREITAS et al., 2017). The NDVI provides information on the conditions of vegetation density and size obtained by the ratio between the difference of the near-infrared and red reflectance and the sum of this reflectance (TUCKER, 1979). This index is influenced by the rainfall in a way that the vegetative vigor increases when rainfall over the region occurs days before the remote data acquisition (GARCÍA, 2012).

Silva et al. (2014), Amorim et al. (2015), and Alves (2017) demonstrated the use of NDVI in studies on the conditions of soil use and soil cover in the Metropolitan Region of Curitiba (PR), Presidente Prudente (SP), and Iporá (GO), respectively. Lourenço \& Landim (2004) mapped the region of Baixada Santista based on the NDVI index for the years of 1989 and 1997. The authors verified the efficiency of the index in identifying the changes in the soil use and soil cover in the region.

Such changes in the terrestrial cover directly affect the radiation and surface energy balance of the region. Consequently, they directly influence the soil surface temperature $\left(\mathrm{T}_{\mathrm{s}}\right)$, which is the main factor for the diagnosis of thermal sensation. Jensen (2009) emphasizes that the $T_{\mathrm{s}}$ is fundamental to understanding the interaction between the Earth's surface and the atmosphere since the $\mathrm{T}_{\mathrm{s}}$ enables identifying "heat spots," which are dimensioned in function of the changes in soil use.

The Urban Heat Islands (UHI) phenomenon, analogous to "heat spots," strongly contrasts the effect of increased temperature on soil compounds-in this case, anthropic constructions. Gartland (2010) states that the UHI formation occurs for adjacent vegetated areas have a lower temperature in relation to the urban area. According to Moraes et al. (2005), the replacement of natural cover by anthropogenic materials provides local heating and induces the formation and intensification of UHI in a given region. Furthermore, Gamarra et al. (2014) and Silva et al. (2014) reported the scarce or absent use of RS as a good alternative for temperature estimation and UHI analysis of the in situ spatial data.

Thus, this study aimed to: $i)$ estimate the $\mathrm{T}_{\mathrm{s}}$ of MRBS and identify UHI formation; and ii) relate the $\mathrm{T}_{\mathrm{s}}$ and NDVI of MRBS from 1986 to 2016, using images from Landsat 5 and 8.

\section{MATERIAL AND METHODS}

\section{Characteristics of the study area}

The MRBS was created by the Complementary State Law No. 815 of June 30, 1996, and consists of nine municipalities: Bertioga, Guarujá, Santos, Ilha de São Vicente, Cubatão, Praia Grande, Mongaguá, Itanhaém, and Peruíbe. About 1.813 million people live in this area, which totals $2445 \mathrm{~km}^{2}$ (Figure 1) (CUNHA \& OLIVEIRA, 2015).

Ilha de São Vicente corresponds to the largest urban area in the MRBS, followed by the center of the city of Santos, the port, and residential areas. Ilha de São Vicente also shows that the urbanization occurred in a discontinuous way, i.e., in the interior of the coastal plain, mostly occupied by low-income families, and in the coastal strips, linearly occupied by touristic lots (Figure 1, study area cut-off).

Ab'Sáber (1965) reported that the region of Serra do Mar has rugged relief and marked slope, the dominion of the hill seas-originally constituted by dense and varied vegetation, belonging to the Atlantic Forest-as well as Coastal Plains, which consist of undergrowth and large mangrove areas. Such characteristics are typical of the MRBS.

\section{Data selection and processing}

The evaluation of the changes in soil use and soil cover in the MRBS was based on obtaining, extracting, and manipulating the data from two sources: i) the 2 nd version of the Climate Hazard Group InfraRed Precipitation with Station data (CHIRPS) (FUNK et al., 2015a), used to obtain the rainfall data; and ii) Landsat Images 5 and 8, used to obtain the NDVI and $\mathrm{T}_{\mathrm{s}}$ of the region.

CHIRPS data result from the integration of satellite images in the infrared channel at the top of the cold clouds (scanning between latitudes $50^{\circ} \mathrm{S}$ $50^{\circ} \mathrm{N}$ ) and surface meteorological stations (SEM). These data are then standardized from artificial neural networks-ANN (FUNK et al., 2015b). The data have spatial resolutions of $0.05^{\circ}$ or $0.25^{\circ}$, and temporal resolutions of three hours, from 1981 to 2018, and are available at the following address: $<\mathrm{ftp}$ //ftp.chg.ucsb.edu/pub/org/chg/products/CHIR PS-2.0>. 

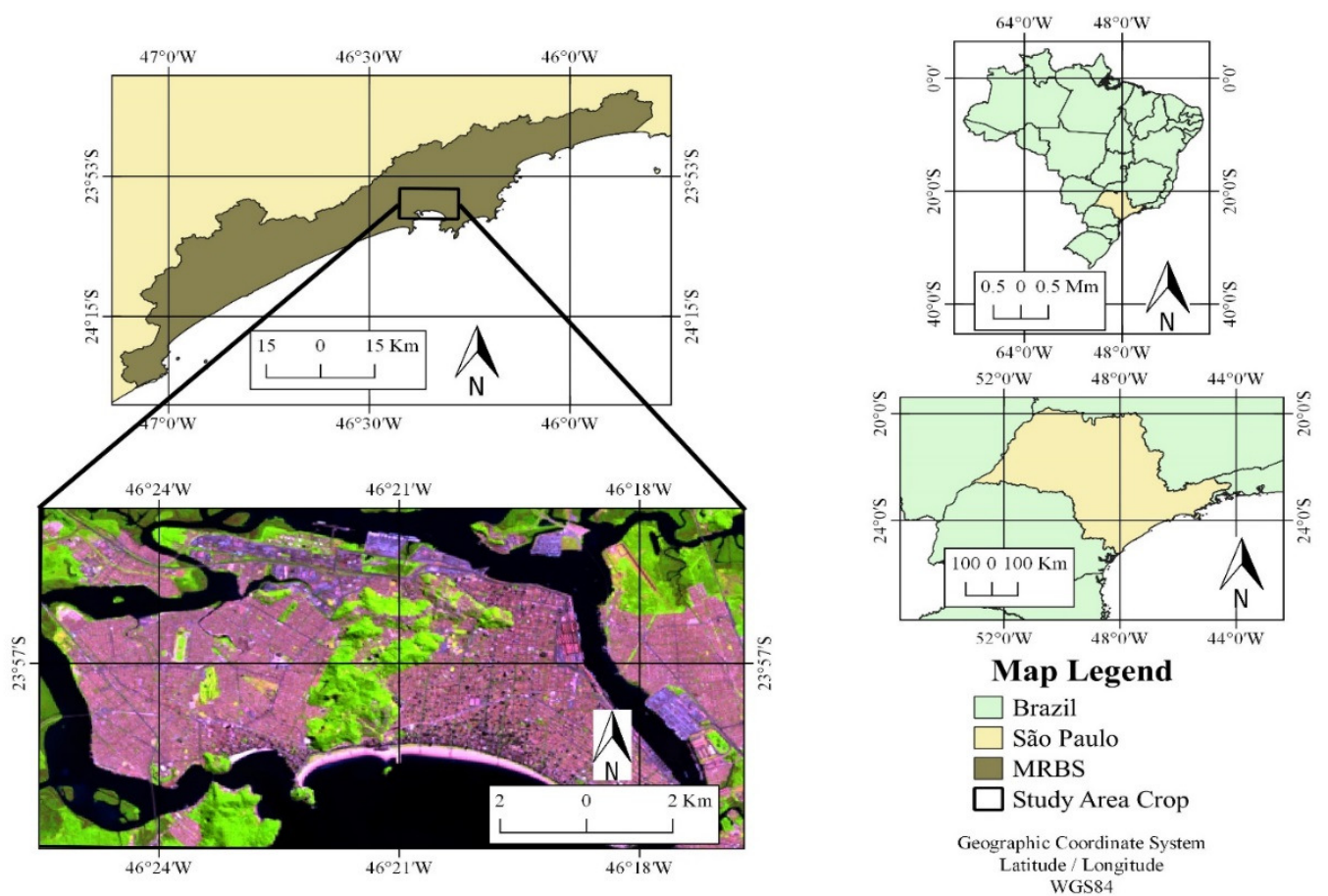

Figure 1. MRBS location map. Highlight the boundaries of the study area in the RGB composition for the date 07/07/2016.

The data obtained from the CHIRPS in regions with high density of stations are consistent, as verified by Funk (2015b), Duan et al. (2016), and Katsanos et al. (2016), and are used as a reference in remote regions or in regions with deficient or absent rainfall cover (PAREDES-TREJO et al., 2017). In this study, monthly data were used with a spatial resolution of $0.05^{\circ} \times 0.05^{\circ}$ (approximately $5.6 \mathrm{~km}$ ). The rainfall data corresponds to the period before the satellite images (ten days before).

The Landsat satellite images were acquired at the following electronic address: https://earthexplorer.usgs.gov/, managed by the United States Geological Survey - USGS (USGS, 2017). According to Pellegatti (2007), the highest rainfall percentage in the MRBS is concentrated in the summer (37\%), followed by the spring and fall (26\%), with lower rainfall concentrated in the winter $(11 \%)$. Due to the greater availability of orbital images without the presence of clouds in the period from 1986 to 2016, the analyses were performed based on the fall period (Table 1).

Table 1. Acquisition date, orbit, quadrant, and azimuth angle $\left(\theta_{\mathrm{SE}},{ }^{\circ}\right)$ from the Landsat images.

\begin{tabular}{|c|c|c|c|c|}
\hline Acquisition date & Time of passage & Orbit & Quadrant & Azimuth angle \\
\hline 05/02/1986 & $12: 29: 46$ & \multirow{10}{*}{219} & \multirow{10}{*}{077} & 47.43 \\
\hline 04/11/1990 & $12: 24: 56$ & & & 55.69 \\
\hline $06 / 22 / 1993$ & $12: 27: 14$ & & & 42.49 \\
\hline $06 / 28 / 1995$ & 12:10:20 & & & 45.89 \\
\hline 06/17/1997 & $12: 34: 15$ & & & 40.92 \\
\hline $06 / 25 / 2000$ & $12: 41: 21$ & & & 39.93 \\
\hline $05 / 06 / 2005$ & $12: 51: 59$ & & & 41.28 \\
\hline $05 / 04 / 2010$ & $12: 55: 33$ & & & 40.97 \\
\hline $04 / 26 / 2013$ & 13:06:30 & & & 40.33 \\
\hline 04/18/2016 & 13:04:19 & & & 43.49 \\
\hline
\end{tabular}


For image processing, the regular cut of the area of interest was performed, which corresponds to $148.46 \mathrm{~km}^{2}$, using the R software version 3.41 ( $\mathrm{R}$ DEVELOPMENT TEAM, 2012) and Quantum GIS - QGIS version 2.18 (QGIS DEVELOPMENT TEAM, 2018). The digital number conversion (ND) and radiometric calibration were performed in reflectance and radiance values, after which the NDVI and $\mathrm{T}_{\mathrm{s}}$ were calculated, as presented below.

The atmospheric correction and conversion of ND values into a monochromatic reflectance of bands 4 and 5 of the OLI (Operational Land Imager) sensor Landsat 8 will be performed according to Eq. 1 (USGS, 2016):

$\rho_{h, i}=\frac{H_{p} Q_{C A L}+A_{p}}{\cos \left(Q_{S E}\right]}$

Wherein $\rho_{\lambda, \mathrm{b}}$ is the monochromatic reflectance of the spectral bands; $\mathrm{H}_{\rho}$ is the coefficient of multiplicative scaling specific to each band $(-0.1) ; A_{\rho}$ is the additive coefficient (constant value $\left.2 * 10^{-5}\right)$; $\mathrm{Q}_{\mathrm{CAL}}$ is the pixel-by-pixel value of each band (ND); and $\theta_{\mathrm{SE}}\left(^{\circ}\right)$ is the azimuth angle (Table 1).

After obtaining the monochromatic reflectance, the NDVI index was calculated according to Eq. 3 (TUCKER, 1979):

$$
\text { NDVI }=\frac{\left(\rho_{V}-\rho_{V}\right)}{\left(\rho_{N}+\rho_{V}\right)}
$$

wherein $\rho_{\mathrm{IV}}$ and $\rho_{\mathrm{V}}$ correspond to the nearinfrared and red bands reflectances, respectively. The NDVI index ranges from -1 to +1 , in which positive values correspond to areas with vegetative vigor (soil surface) and vary according to the photosynthetic activity of the plants and their density in the considered area (pixel). Conversely, in surfaces such as water and clouds, the NDVI is usually lower than zero.

First, the monochromatic radiance (Eq. 4) is calculated for the band 10 of the TIRS sensor (Thermal Infrared Sensor) Landsat 8.

$L_{2}=M_{L} Q_{C A L}+A_{L}$

wherein $\mathrm{L}_{\lambda}$ is the spectral radiance at the top of the atmosphere; $\mathrm{M}_{\mathrm{L}}$ is the specific multiplicative coefficient $\left(\mathrm{M}_{\mathrm{L}}=5.5375^{*} 10^{-2}\right.$ for Landsat 5; $\mathrm{M}_{\mathrm{L}}=3.342 * 10^{-4}$ for Landsat 8 ); and $\mathrm{A}_{\mathrm{L}}$ is the specific additive coefficient $\left(A_{L}=1.18243\right.$ for Landsat 5; $\mathrm{A}_{\mathrm{L}}=0.1$ for Landsat 8).

$$
T s=\frac{T_{s} \text { is estimated according to Eq. } 5:}{\ln \left(\frac{k_{1}}{L_{\lambda}}+1\right)}
$$

wherein $\mathrm{T}_{\mathrm{s}}$ is the surface temperature $\left({ }^{\circ} \mathrm{C}\right)$ for Landsat 5 satellite; and the values of $\mathrm{K}_{1}$ and $\mathrm{K}_{2}$ correspond to 607.76 and 1260.56 (Landsat 5), respectively, or 774.88 and 1321.08 (Landsat 8), respectively.

Images of the Landsat 5 and 8 satellites were processed using the QGIS software, version 2.18 (QGIS DEVELOPMENT TEAM, 2018), and the $\mathrm{R}$ environment, version 3.41 ( $\mathrm{R}$ DEVELOPMENT TEAM, 2014), which generated thematic maps of NDVI and $T_{s}$. The results of these maps were separated into five classes, in a supervised way: (1) Classes 1 - Water Bodies, with values between -1.00 and -0.15 ; (2) Class 2 - Local urban grid, with values between -0.15 and 0.10 ; (3) Class 3 - Exposed soil and road corridors, with values between 0.10 and 0.35 ; (4) Class $4-$ Shrub substrate, with values between 0.35 and 0.60 ; and (5) Class 5 - Dense vegetation, with values between 0.60 and 1.00 (TUCKER, 1979; HUETE \& TUCKER, 1991; MELO et al., 2017; FREITAS et al., 2017). This classification will assist the diagnosis of the variability of soil use and soil cover over the study period in the region.

\section{RESULTS AND DISCUSSION}

Results for NDVI and $T_{s}$ of the MRBS, from 1986 to 2016, in the fall (April-May-June), are shown in Figures 2-6 and Tables 2 and 3. Table 2 shows the soil cover percentage $(\%)$ of each of the five classes established in item 2.2 over the 30 years. The area covered by water bodies $(24.9 \% \pm$ $2.5 \%$ ) has a lower variation over the period. The highest cover percentage for this class corresponds to $27.4 \%$ (20.6\%), registered in 1997 (1993). Figures 2 and 3 evidence this behavior since the intensity of the blue color (designated for water bodies) decreased over the years. Moreover, a significant variation was detected over the study period in a southwestern islet (SW) of the thematic maps, showing higher cover in Figure 3D (Figure

\begin{tabular}{|c|c|c|c|c|c|c|}
\hline Soil cover & Classes & 1986 & 1990 & 1993 & 1995 & 1997 \\
\hline Water Bodies & $(-1.00)-(-0.15)$ & 26.9 & 24.6 & 20.6 & 23.8 & 27.4 \\
\hline Urban grid & $(-0.15)-0.10$ & 27.2 & 28.9 & 38.6 & 35.2 & 34.4 \\
\hline $\begin{array}{l}\text { Exposed soil and road } \\
\text { corridors }\end{array}$ & $0.10-0.35$ & 26.4 & 22.9 & 22.5 & 21.8 & 19.2 \\
\hline Shrub substrates & $0.35-0.60$ & 18.3 & 19.0 & 18.0 & 18.4 & 17.7 \\
\hline
\end{tabular}
$2 \mathrm{~A})$, which is associated with the tide variation.

Table 2. Classes of soil cover identified from the NDVI (\%) between 1986 and 2016. 
Space-temporal evaluation...

ALVES, L. E. R. et al

\begin{tabular}{|c|c|c|c|c|c|c|}
\hline Dense vegetation & $0.60-1.00$ & 1.2 & 4.6 & 0.3 & 0.8 & 1.3 \\
\hline Soil cover & Classes & 2000 & 2005 & 2010 & 2013 & 2016 \\
\hline Water Bodies & $(-1.00)-(-0.15)$ & 25.8 & 26.4 & 26.2 & 21.0 & 20.7 \\
\hline Urban grid & $(-0.15)-0.10$ & 41.3 & 32.3 & 36.9 & 37.9 & 35.2 \\
\hline $\begin{array}{l}\text { Exposed soil and road } \\
\text { corridors }\end{array}$ & $0.10-0.35$ & 16.7 & 17.5 & 14.2 & 32.4 & 32.4 \\
\hline Shrub substrates & $0.35-0.60$ & 16.1 & 18.4 & 18.6 & 8.6 & 11.6 \\
\hline Dense vegetation & $0.60-1.00$ & 0.1 & 5.5 & 4.1 & 0.1 & 0.1 \\
\hline
\end{tabular}

Regarding the urban grid, the cover area in the MRBS increased from $27.2 \%$ in 1986 to $34.4 \%$ in 1997, which corresponds to a $14.1 \%$ increase over 14 years in the time range. From 2000 to 2016, specifically in 2013 and 2016, values ranged from $32.3 \%$ to $37.9 \%$, respectively. The urban grid $(34.3 \% \pm 5.4 \%)$ stood out in relation to the other classes. The increased urban grid cover occurred mainly in the west (W) portion of Ilha de São Vicente (Figure 2 and 3), where some areas exhibited NDVI values between 0.10 and 0.60 . This behavior was visualized in 1986. Over time, a substantial increase in the density of "urban voids" (unoccupied areas) was detected, and between 2010 and 2016, these voids were fully occupied (Figures 3C, 3D and 3E). Mello et al. (2013) obtained similar results in a study that evaluated the municipality of São Vicente using orthogonal aerial photographs from 1963 to 2007.

The third class, exposed soil and road corridors, had a significant decrease in the cover area (from $27.2 \%$ to $14.3 \%$ ) between 1986 and
2010. However, between 2013 and 2016, a significant increase of $32.4 \%$ was recorded in both cases. This increase is due to the urban expansion in the region, which is associated with the growth of irregular urban areas and occupation of natural areas as a result of roads construction and deforestation in the MRBS (Mello et al., 2013). This behavior was identified by the reduction of vegetation cover in the mangrove areas. Similar to the results of the urban grid class, Figures 2 and 3 show a remarkable reduction in NDVI values in the temporal scale, especially in 2013 (Figure 3D) and 2016 (Figure 3E).

The fourth class, shrub substrate, showed a significant decrease in the cover area (from 18.3\% in 1986 to $11.6 \%$ in 2016). This class has little variation (standard deviation of $1.0 \%$ ). However, its cover area reduced $(-2.9 \%)$. When evaluating the municipality of Ilha de São Vicente, Mello et al. (2013) verified the same decrease, as natural mangrove areas were irregularly occupied in the $\mathrm{W}$ portion of the island (Figures 2 and 3).

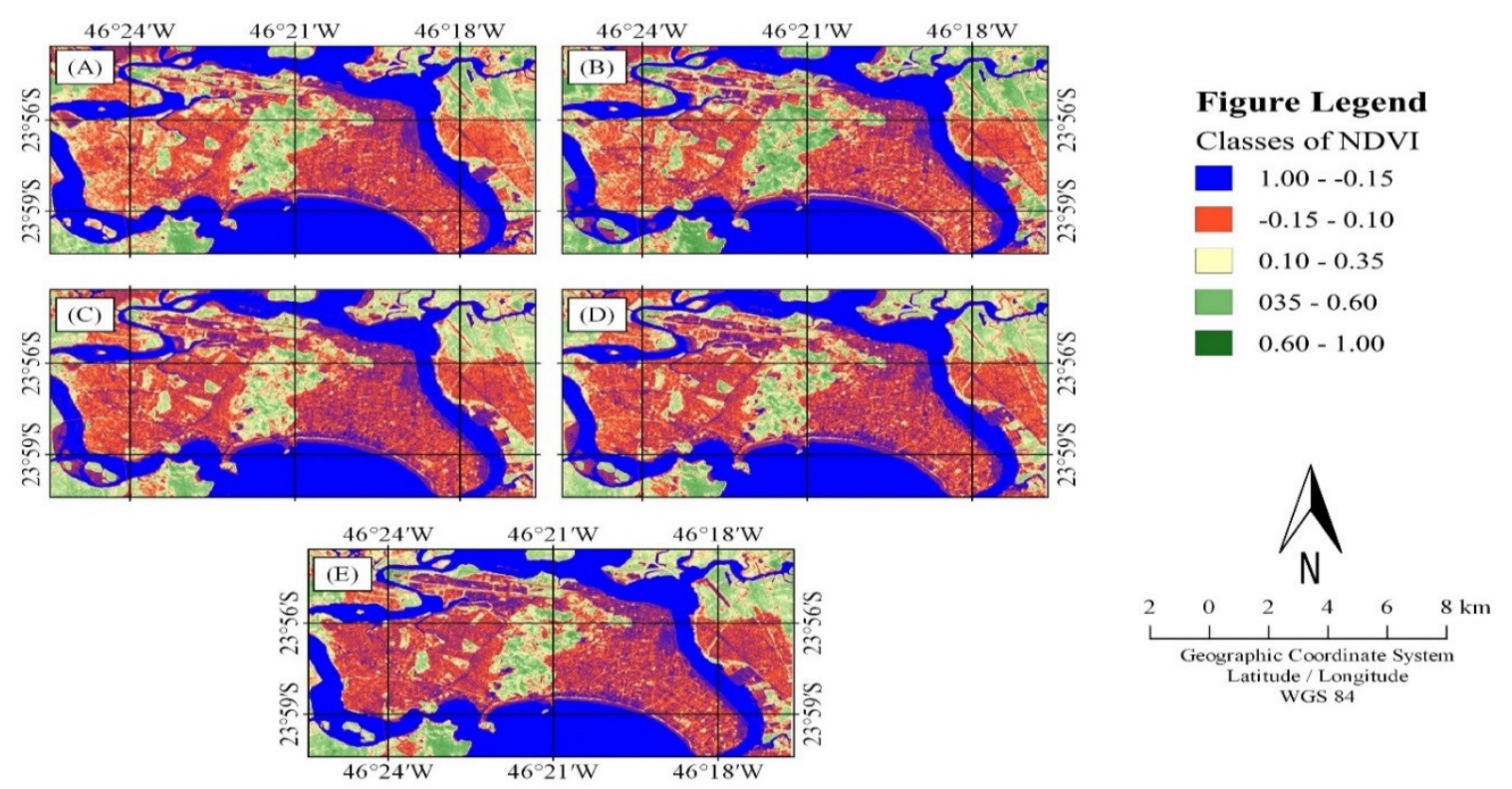

Figure 2. NDVI Map for 1986 (A), 1990 (B), 1993 (C), 1995 (D), and 1997 (E). 

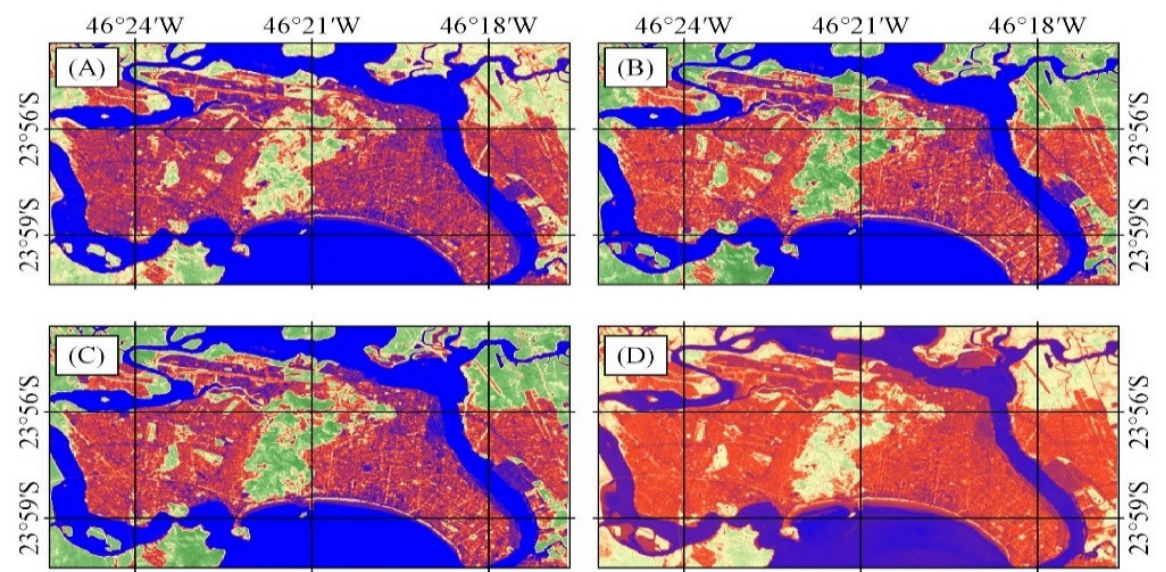

Figure Legend

Classes of NDVI

$1.00--0.15$

$-0.15-0.10$

$0.10-0.35$

$035-0.60$

$0.60-1.00$

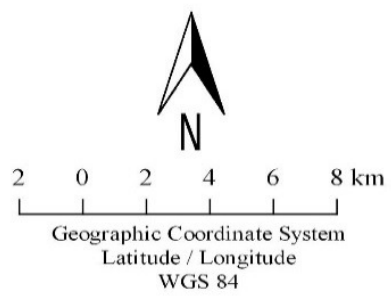

Figure 3. NDVI Map for 2000 (A), 2005 (B), 2010 (C), 2013 (D), and 2016 (E).

The dense vegetation class exhibited the lowest cover area among the evaluated classes. The cover reduction of this area was evidenced by the results of $2016(0.1 \%)$. This class, which is related to the area with dense vegetation or natural restoration of mangroves with high cover density, had NDVI values between 0.60 and 1.00. However, its extension is limited due to the little cover (Figures 2 and 3).

In general, the variation in the classes cover highlighted in this study for the MRBS cut-off area over the studied period showed a reduction in the cover area in three classes: urban grid (-23\%), shrub substrate $(-36.6 \%)$, and dense vegetation $(-91.7 \%)$. Nevertheless, an increase was observed in the urban grid (29.4\%) and exposed soil and road corridors $(22.7 \%)$. The NDVI mapping showed that anthropic occupation and vegetation deforestation contributed to reducing the shrub substrate and dense vegetation areas. This reduction is due to the high urbanization degree characteristic of Metropolitan Regions (MR) (Moraes et al. 2005; Goulart et al., 2015), conditioned by property speculation and regional development, as confirmed by Afonso (2005). This author also reported that the areas occupied are not suitable for urban use, such as mangroves, estuarine channels, rivers, and continuous forest.

The differences in the values, pixel by pixel, between the last (2016) and the first (1986) images collected were determined to evaluate the NDVI gain or loss changes (Figure 4). The result of this difference pointed to a substantial reduction in the NDVI values on the terrestrial surface areas, especially in Morro do Marapé, located in the center of the map, due to irregular soil occupation. The western portion of Ilha de São Vicente (Figure 4) showed a decreased NDVI owing to the urban density. Mello et al. (2013) previously reported the urban grid growth in this region.

The NDVI value increased in the water bodies, which is $59.39 \%$ of the total area. Conversely, the areas with higher vegetative vigor (classes 4 and 5, NDVI $>0.35$ ) had a lower index, which corresponds to $40.35 \%$ of the total area. This reduction is associated with human activities in the area. However, it might be associated with the total rainfall preceding the satellite passage, which influences the vegetative vigor. This phenomenon is evidenced by the fact that approximately $170 \mathrm{~mm}$ rainfall occurred before the satellite passage in 1986, while no rainfall was recorded in 2016 (CLIMANALISE, 2008). Only $0.26 \%$ of the total area did not change. The NDVI values for the evaluated period show that the lowest (highest) absolute value was $-0.649(0.666)$. The mean value of the variation was 0.021 , with a standard deviation of $11.8 \%$. 


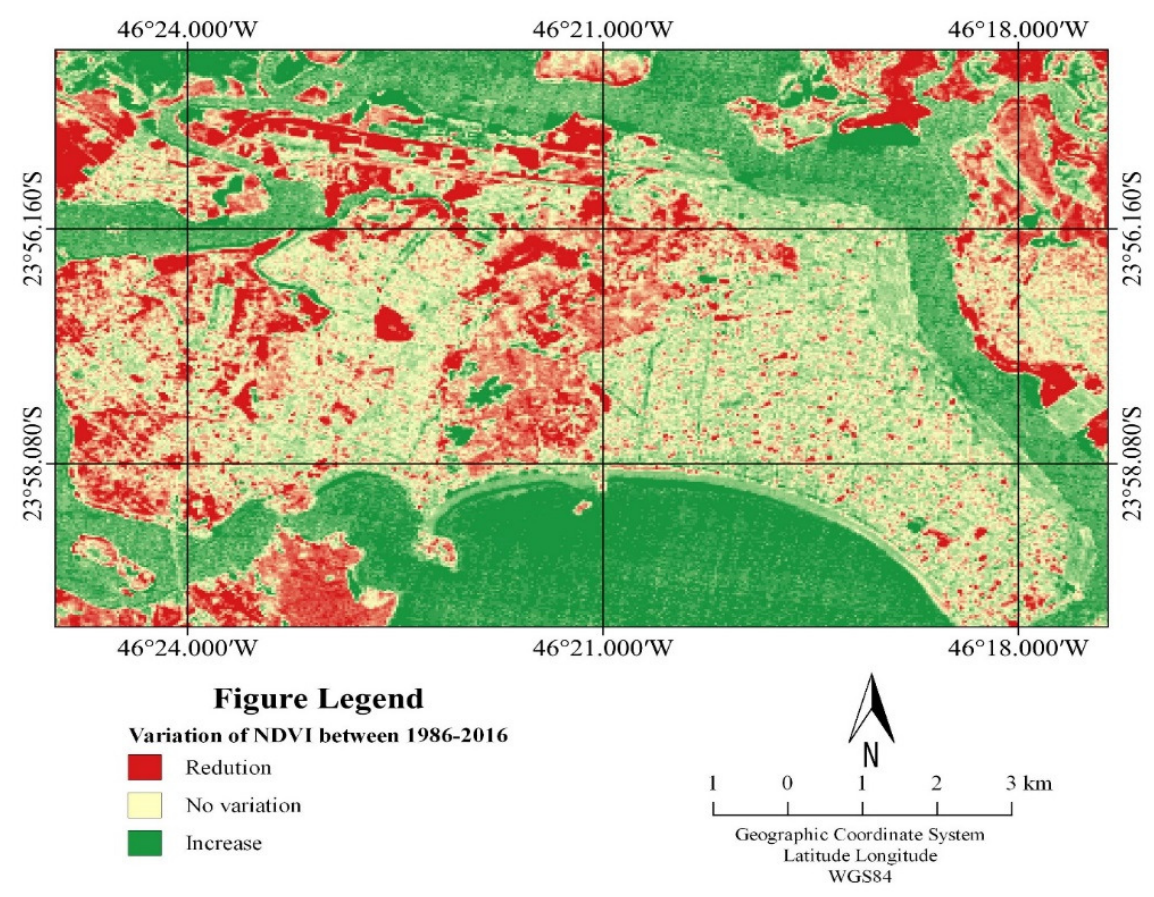

Figure 4. Variation of NDVI between 1986 and 2016.

The thematic maps of $\mathrm{T}_{\mathrm{s}}$ (Figures 5 and 6) of the study period show an increase in the $T_{s}$ of the urban grid. In 1986, the $T_{\mathrm{s}}$ ranged between 24 and $28^{\circ} \mathrm{C}$, and in 2016 , values were higher than $32^{\circ} \mathrm{C}$. The increase in temperature is not evident in the period from 1986 to 1997 since the highest temperatures were observed in 1986 (Figure 5A) and 1990 (Figure 5B), and the lowest temperature was recorded in 1993 (Figure 5C). However, after this year, the temperature increased again, maintaining this pattern until 2016. This behavior follows the pattern of the urban grid growth observed in the NDVI thematic maps (Figures 2, 3 and 4) since the density of urban areas increased waterproof areas, such as asphalt, paved streets, and construction of residential and commercial areas (AFONSO, 2005; MELLO et al., 2013).

The higher $\mathrm{T}_{\mathrm{s}}$ values are concentrated in the urban grid (Figures 5 and 6), mainly consisting of paved areas of asphalt, residential and commercial buildings, industries, warehouses, and ports. These areas had the lowest values of terrestrial NDVI, between -0.15 and 0.35 . The adjacent areas showed a lower temperature than the urban grid. Also, the lower temperatures were observed in water bodies. Results of this study corroborate those of Gamarra et al. (2014), Barros \& Lombardo (2016), and Santiago \& Gomes (2016), who evaluated UHI in Londrina - PR, São Paulo - SP, and Maceió - AL, respectively. The authors claim that the replacement of the existing soil cover by the urban grid from the urban expansion favors the increase in $\mathrm{T}_{\mathrm{s}}$.
The analysis of the temporal behavior from 1986 to 2016 (Figures 5 and 6) reveals a gradual increase in the $\mathrm{T}_{\mathrm{s}}$ of the region (around $8^{\circ} \mathrm{C}$ ), mainly in the urbanized area. High temperatures affect the environment, as well as the well-being of people living in the region.

Figure 5, which corresponds to the period from 1986 to 1997, shows that, according to the data extracted from the CHIRPS (Table 3), the total rainfall preceding the passage of the Landsat was high, i.e., higher than $25 \mathrm{~mm}$ in ten days. Conversely, no rainfall was registered in the period from 2000 to 2016 (Figure 6).

Rainfall may have influenced the final $\mathrm{T}_{\mathrm{s}}$ estimate values since the available surface water converts the incident solar radiation into latent heat for evaporation, while the totally-dry surface converts this radiation into sensible heat, which increases the temperature.

The cover area of the $T_{\mathrm{s}}$ classes shown Table 4 from 1986 to 1997 does not exceed $28^{\circ} \mathrm{C}$. Conversely, in the second period, from 2000 to 2016, values were higher than $32^{\circ} \mathrm{C}$. The lowest $\mathrm{T}_{\mathrm{s}}$ class $\left(8-16^{\circ} \mathrm{C}\right)$ occurred only in 1997 , with a cover area of $0.1 \%$. The second $\mathrm{T}_{\mathrm{s}}$ class $\left(16-20^{\circ} \mathrm{C}\right)$ occurred in almost all evaluated years, except for 1990, 2010, 2013, and 2016; this class also had higher cover in $1993(81.4 \%)$ and 1997 (72.6\%). The first class exhibited a standard deviation of 7.14\% between 1986 and 2016, while the second class had a standard deviation of $30.32 \%$, evidencing the high variability of the second $\mathrm{T}_{\mathrm{s}}$ class during this period. 


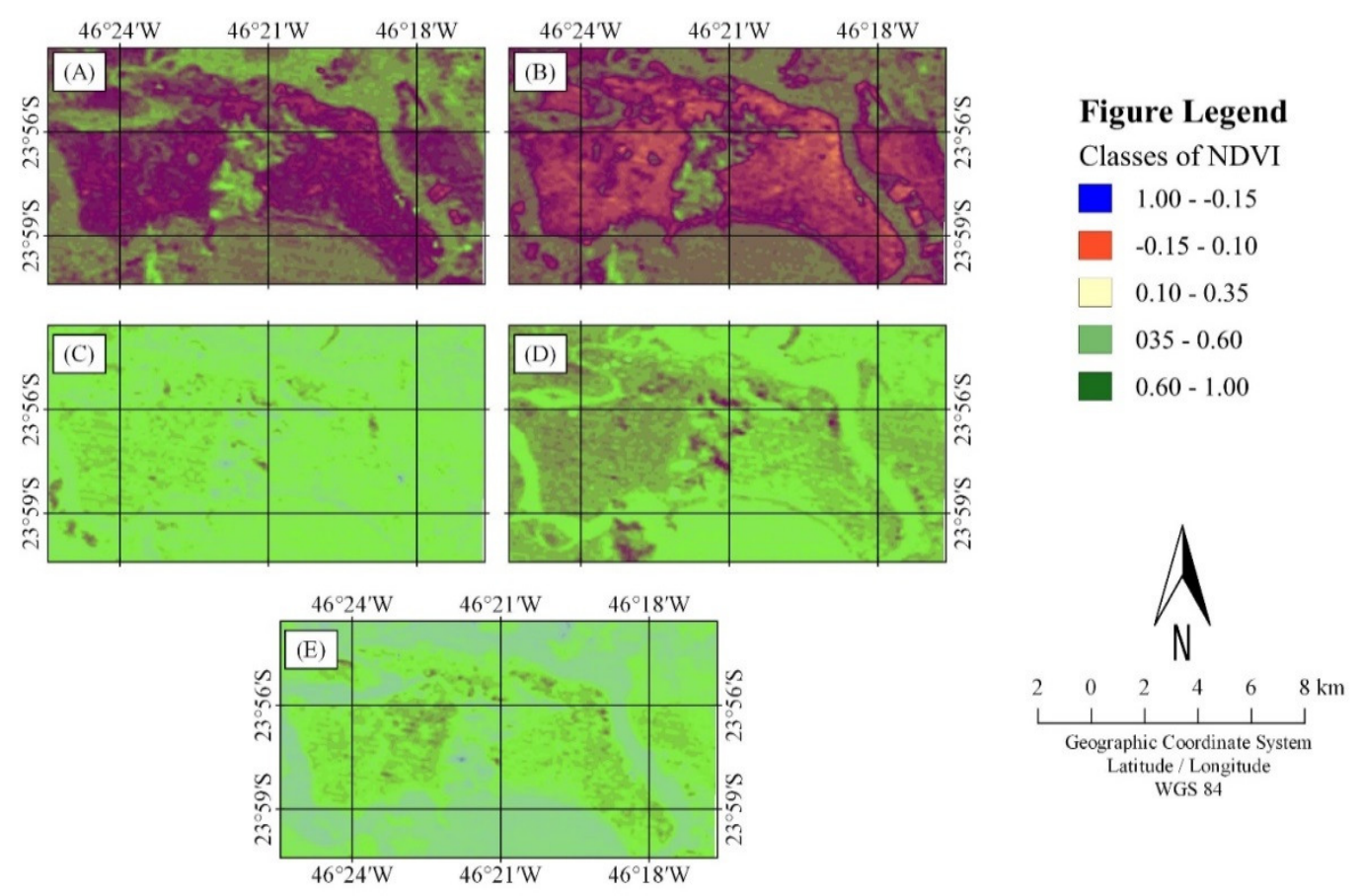

Figure 5. $\mathrm{T}_{\mathrm{s}}$ map for 1986 (A), 1990 (B), 1993 (C), 1995 (D), and 1997 (E).
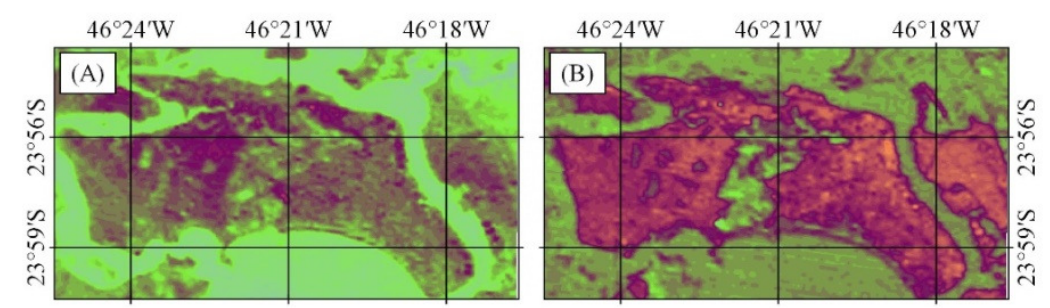

\section{Figure Legend}

Classes of NDVI

$1.00--0.15$

$-0.15-0.10$

$0.10-0.35$
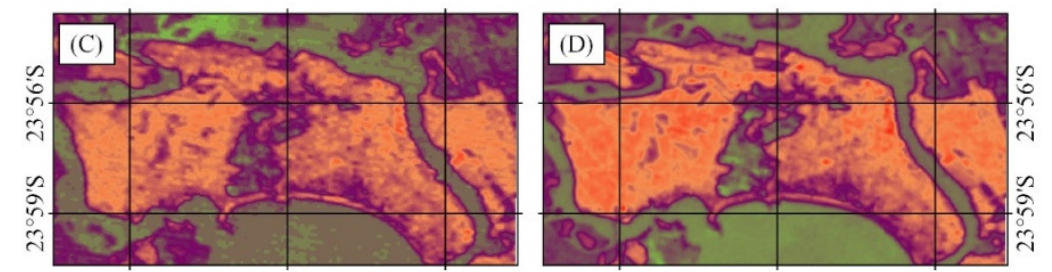

$035-0.60$

$0.60-1.00$
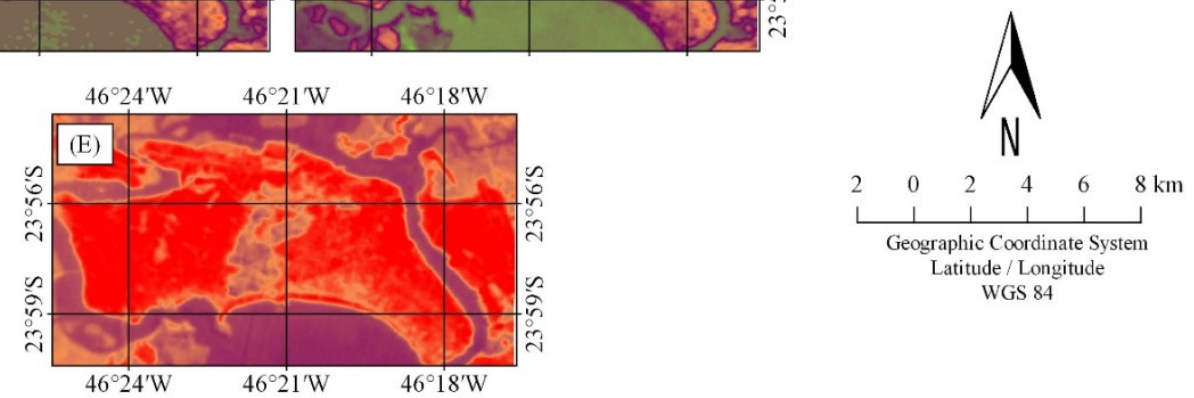
WGS 84

Figure 6. $T_{\mathrm{s}}$ map for 2000 (A), 2005 (B), 2010 (C), 2013 (D), and 2016 (E).

Table 3. Cumulative rainfall $(\mathrm{mm})$ of ten days preceding passage of the Landsat 5 and 8 satellites.

\begin{tabular}{ll} 
Passage date & Prece \\
\hline $05 / 02 / 1986$ & $\mathbf{8 5 . 2 5}$ \\
$04 / 11 / 1990$ & $\mathbf{8 1 . 5 0}$ \\
$06 / 22 / 1993$ & $\mathbf{8 9 . 5 0}$ \\
$06 / 28 / 1995$ & $\mathbf{6 7 . 7 5}$
\end{tabular}


Table 4. Cover area (\%) of surface temperature classes $\left(\mathrm{T}_{\mathrm{s}}\right)$ from 1986 to 2016.

\begin{tabular}{llllll}
\hline Classes $\left({ }^{\circ} \mathbf{C}\right)$ & $\mathbf{1 9 8 6}$ & $\mathbf{1 9 9 0}$ & $\mathbf{1 9 9 3}$ & 1995 & $\mathbf{1 9 9 7}$ \\
\hline $\mathbf{8 - 1 6}$ & 0.0 & 0.0 & 0.0 & 0.0 & 0.1 \\
$\mathbf{1 6 - 2 0}$ & 0.1 & 0.0 & 81.4 & 29.9 & 72.6 \\
$\mathbf{2 0 - 2 4}$ & 82.3 & 55.1 & 18.6 & 70.0 & 27.3 \\
$\mathbf{2 4 - 2 8}$ & 17.6 & 44.9 & 0.0 & 0.0 & 0.0 \\
$\mathbf{2 9 - 3 2}$ & 0.0 & 0.0 & 0.0 & 0.0 & 0.0 \\
$\mathbf{> 3 2}$ & 0.0 & 0.0 & 0.0 & 0.0 & 0.0 \\
Classes $\left({ }^{\circ} \mathbf{C}\right)$ & 2000 & $\mathbf{2 0 0 5}$ & $\mathbf{2 0 1 0}$ & 2013 & $\mathbf{2 0 1 6}$ \\
$\mathbf{8 - 1 6}$ & 0.0 & 0.0 & 0.0 & 0.0 & 0.0 \\
$\mathbf{1 6 - 2 0}$ & 34.1 & 0.1 & 0.0 & 0.0 & 0.0 \\
$\mathbf{2 0 - 2 4}$ & 64.2 & 60.2 & 44.3 & 46.0 & 0.0 \\
$\mathbf{2 4 - 2 8}$ & 1.7 & 39.7 & 51.0 & 36.1 & 46.1 \\
$\mathbf{2 9 - 3 2}$ & 0.0 & 0.0 & 4.7 & 17.9 & 41.7 \\
$\mathbf{> 3 2}$ & 0.0 & 0.0 & 0.0 & 0.0 & 12.1 \\
\hline
\end{tabular}

The third $\mathrm{T}_{\mathrm{s}}$ class $\left(20-24^{\circ} \mathrm{C}\right)$ (Table 4$)$ had no cover only in 2016, the hottest year in the analyzed period. This class had a mean cover of approximately $44.44 \%$ in that period, which was the highest among all classes evaluated. Furthermore, its highest cover was observed in $1986(82.3 \%)$. The fourth class $\left(24-28^{\circ} \mathrm{C}\right)$ presents a mean cover of $24.11 \%$ (Table 4 and Figures 5 and 6) and the highest cover in $2010(1993,1995$, and 1997).

The fifth class $\left(29-32^{\circ} \mathrm{C}\right)$ had no spatial cover from 1986 to 2000 (Table 4 and Figure 6). However, it exhibited the highest cover in 2016, followed by the standard deviation of $12.94 \%$, and a mean of $13.66 \%$ between 2000 and 2016 . The the last class, which corresponds to values $\mathrm{T}_{\mathrm{s}}>32^{\circ} \mathrm{C}$, was only observed in 2016 , with a cover of $12.1 \%$, corresponding to the urban grid (Figures 2 and 3).

\section{CONCLUSIONS}

The NDVI mapping showed a significant reduction in the cover area corresponding to the dense vegetation class (91.7\%). Conversely, the urban grid category increased by $29.4 \%$, resulting from urban expansion and green cover reduction throughout the region over this period.

Surface temperature thematic maps showed high-temperature values related to increased urbanization and decreased rainfall. Also, an $8^{\circ} \mathrm{C}$ rise in surface temperature over the last 30 years was registered. This phenomenon is due to regional development, which has replaced natural soils by anthropic materials and reduced dense vegetation. This fact has resulted in the formation and intensification of UHI, especially after the 2000s.

\section{ACKNOWLEDGMENTS}

The first author thanks CNPq for granting a Master's Degree. The fourth author thanks CNPq for the research productivity grant, process number 306410/2015-0.

RESUMO: A Região Metropolitana da Baixada Santista (RMBS) abriga uma das principais zonas portuárias do Brasil, o Porto de Santos. Devido ao grau de urbanização dessa região, o monitoramento dos parâmetros biofísicos torna-se fundamental. Desta forma, este estudo tem como objetivo i) estimar a Temperatura de superfície terrestre $\left(T_{s}\right)$ da RMBS, seguido da identificação da formação de ICU e ii) relacionar a $\mathrm{T}_{\mathrm{s}}$ e o NDVI da RMBS no período de 1986 a 2016, a partir das imagens do Landsat 5 e 8 . A análise espacial 
foi baseada no Normalized Difference Vegetation Index (NDVI), no sentido de verificar as condições da densidade e porte da vegetação a partir de cinco classes previamente estabelecidas (Corpo d'água, Malha urbana, Solo exposto e corredores viários, Substrato Arbustivo e Vegetação densa). Os mapas de NDVI indicam uma redução significativa na área de cobertura correspondente à classe vegetação densa, com o valor de cobertura de $91,7 \%$. Por outro lado, a classe Malha urbana apresentou um aumento de $29,4 \%$, resultantes da expansão urbana e da redução da cobertura verde na RMBS ao longo do período. Os mapas temáticos de $\mathrm{T}_{\mathrm{s}}$ mostraram altos valores de temperatura, relacionados ao aumento da malha urbana e redução da precipitação. Além disso, houve um aumento de $8^{\circ} \mathrm{C}$ na $\mathrm{T}_{\mathrm{s}}$ nos últimos 30 anos, causados pelo avanço do desenvolvimento regional, associados à substituição do solo natural por materiais antrópicos e à redução da vegetação densa. Esses fatores resultaram no surgimento de ICU e sua intensificação a partir dos anos 2000.

PALAVRAS-CHAVE: Índice de vegetação. Série temporal. Ilha de calor urbano.

\section{REFERENCES}

AB’SÁBER, A. N. Domínios morfoclimáticos do território brasileiro. São Paulo: Edusp,1965.

AFONSO, C. M. Transformação ambiental e paisagística na Baixada Santista, SP. Paisagem Ambiente. São Paulo, n. 20, p. 85-130, 2005. https://doi.org/10.11606/issn.2359-5361.v0i20p85-130

AGHAKOUCHAK, A.; FARAHMAND, A.; MELTON, F. S.; TEIXEIRA, J.; ANDERSON, M. C.; WARDLOW, B. D.; HAIN, C. R.. Remote sensing of drought: Progress, challenges and opportunities. Reviews of Geophysics, Rome, v. 53, n. 2, p. 452-480, 2015. https://doi.org/10.1002/2014RG000456

ALVES, E. D. L. Ilha de calor urbana em cidade de pequeno porte e a influência de variáveis geourbanas.

Revista Brasileira de Climatologia, Curitiba, v. 20, jan/jul., 2017.

https://doi.org/10.5380/abclima.v20i0.46190

ALVES, L. E. R.; GOMES, H. B.; SANTOS, M. N.; FREITAS, I. G. F. Balanço de radiação através do satélite Landsat-8 na bacia do Rio Pajeú, Revista do Departamento de Geografia, São Paulo, v. 33, n. 1, p. 117-127, 2017. https://doi.org/10.11606/rdg.v33i0.124577

AMORIM, M. C. C. T.; DUBREUIL, V.; CARDOSO, R.S. Modelagem espacial da ilha de calor urbana em Presidente Prudente (SP) - Brasil. Revista Brasileira de Climatologia, CuritIba, v. 16, jan/jul., 2015. https://doi.org/10.5380/abclima.v16i0.40585

BARROS, H. R.; LOMBARDO, M. A. A ilha de calor urbano e o uso e cobertura do solo em São Paulo-SP, GEOUSP - Espaço e Tempo, São Paulo, v. 20, n. 1, p. 160-177, 2016. https://doi.org/10.11606/issn.21790892.geousp.2016.97783

BASTIAANSSEN, W. G. M. SEBAL-based sensible and latent heat fluxes in the irrigated Gediz Basin, Journal of Hidrology, Turkey, v. 229, n. 1, p. 87-100, 2000. https://doi.org/10.1016/S0022-1694(99)00202-4

CAÚlA, R. H.; OLIVEIRA-JÚNIOR, J. F.; GOIS, G.; DELGADO, R. C.; PIMENTEL, L. C. G.; TEODORO, P. E. Nonparametric statistics applied to fire foci obtained by meteorological satellites and their relationship to the MCD12Q1 product in the state of Rio de Janeiro, Southeast - Brazil, Land Degradation \& Development, Londres, v. 28, n.3, p. 1056-1067, 2016. https://doi.org/10.1002/ldr.2574

CLEMENTE, S. S.; OLIVEIRA JÚNIOR, J. F.; LOUZADA, M. A. P. Focos de Calor na Mata Atlântica do Estado do Rio de Janeiro. Revista Brasileira de Meteorologia, São Paulo, v. 32, n. 4, p. 669-677, 2017. https://doi.org/10.1590/0102-7786324014

CLIMANÁLISE. Boletim Climanálise INPE/CPTEC. 2018. Acessível a partir de: http://www.cptec.inpe.br / rclimanl/boletim/ 
CUNHA, C. M. L.; OLIVEIRA, R. C. orgs. Baixada Santista: uma contribuição à análise geoambiental. São Paulo: Editora UNESP, 2015, 250 p. https://doi.org/10.7476/9788568334553

DUAN Z.; LIU, J.; TUO Y.; CHIOGNA, G.; DISSE, M. Evaluation of eight high spatial resolution gridded precipitation products in Adige Basin (Italy) at multiple temporal and spatial scales, Science of The Total Environment, v. 573, p. 1536-1553, 2016. https://doi.org/10.1016/j.scitotenv.2016.08.213

FREITAS, I. G.; ALVES, L. E. R.; GOMES, H. B.; JÚNIOR, J. R. S.; SANTIAGO, D. B.; SILVA, R. A. Analysis of Behavior of Vegetation in the Year of 2016 for the Municipality of Remanso-BA. Revista Geama, Recife, v. 3, n. 3, p. 149-156. 2017.

FUNK, C.; PETERSON, P.; LANDSFELD, M.; PEDREROS, D.; VERDIN, J.; SHUKLA, S.; HUSAK, G.; ROWLAND, J.; HARRISON, L.; HOELL, A.; MICHAELSEN, J. The climate hazards infrared precipitation with record for monitoring extremes. Scientific Data, Virginia, v. 2, p. 10-66, 2015 a.

https://doi.org/10.1038/sdata.2015.66

FUNK, C.; VERDIN, A.; MICHAELSEN, J.; PETERSON, P.; PEDREROS, D.; \& HUSAK, G.A. global satellite-assisted precipitation climatology. Earth System Science Data, Mainz, 7(2), p. 275-287, 2015 b. http://dx.doi.org/10.5194/essd-7-275-2015b https://doi.org/10.5194/essd-7-275-2015

GAMARRA, N. L. R.; CORRÊA, M. P.; TARGINO, A. C. L. Utilização de Sensoriamento Remoto em Análise de Albedo e Temperatura de Superfície em Londrina-Pr: Contribuições para Estudos de Ilhas de Calor Urbanos. Revista Brasileira de Meteorologia, São José dos Campos, v. 29, n. 4, p. 537-550, 2014. https://doi.org/10.1590/0102-778620130671

GARTLAND, L. Ilhas de calor. São Paulo: Oficina dos Textos, 2010. 248 p.

GOMES, H. B.; SILVA, B. B.; CAVALCANTE, E. P.; ROCHA, H. R. Balanço de radiação em diferentes biomas no estado de São Paulo mediante imagens Landsat-5. Geociências, São Paulo, v. 28, n. 2, p. 153-164, 2009.

GOULART, A. C. O.; DELGADO, R. C.; OLIVEIRA JÚNIOR, J. F.; GOIS, G.; OLIVEIRA, E. S. Relação espectro-temporal entre índices de vegetação e a chuva na cidade do Rio de Janeiro. Revista de Ciências Agrárias, Belém, v. 58, n. 3, p. 277-283, 2015. https://doi.org/10.4322/rca.1990

HUETE, A. R. \& TUCKER, C. J. Investigation of soil influence in AVHRR red and near infrared vegetation index imagery. International Journal of Remote Sensing, Virginia, v. 12, n. 1, p. 1223-1242, 1991. https://doi.org/10.1080/01431169108929723

JENSEN, J. R. Sensoriamento Remoto do Ambiente: uma perspectiva em recursos terrestres, $2^{\text {a }}$ Ed. traduzida pelo Instituto Nacional de Pesquisas Espaciais - INPE, São Paulo, Parêntese, 672 p., 2009.

KATSANOS D., RETALIS, A., MICHAELIDES, S. Validation of a high-resolution precipitation database (CHIRPS) over Cyprus for a 30-year period. Atmospheric Research, Léon, v. 169, Part B, p. 459-464, 2016. https://doi.org/10.1016/j.atmosres.2015.05.015

LOURENÇO, R. W.; LANDIM, P. M. B. Estudo da Variabilidade do Índice de Vegetação por Diferença Normalizada/NDVI Utilizando Krigagem Indicativa. HOLOS Environment, Rio Claro, v. 4, n. 1, p. 38-55, 2004.

MELLO, K.; TOPPA, R. H.; ABESSA, D. M. D.; CASTRO, M. Dinâmica da expansão urbana na zona costeira brasileira: o caso do município de São Vicente, São Paulo, Brasil. Revista de Gestão Costeira

Integrada/Journal of Integrated Coastal Zone Management, Porto, v. 13, n. 4, p.539-551, 2013. https://doi.org/10.5894/rgci432 
MELO, J. A. A.; GOMES, H. B.; ALVES, L. E. R.; MELO, J. A.; ARAUJO, I. L. Analysis of the Vegetation Density of the Rio Pajeú Watershed using TM - Landsat 5 Data. Revista Geama, Recife, v. 3, n. 3, p. 157-162. 2017.

MORAES, N. O.; PIMENTEL, L. C. G.; MARTON, E. Simulações Numéricas da Formação de Ilha de Calor na Região Metropolitana do Rio de Janeiro. Anuário do Instituto de Geociências, Rio de Janeiro, v. 28, n. 2, p. 116-138, 2005.

OLIVEIRA-JÚNIOR, J. F.; LYRA, G. B.; SPERANDIO, L. Modelos de Zolnier e Campbell-Norman para estimativa da temperatura do ar no Rio de Janeiro. Revista Brasileira de Engenharia Agrícola e Ambiental (Online), Campina Grande, v. 19, p. 727-733, 2015. https://doi.org/10.1590/1807-1929/agriambi.v19n8p727733

PAREDES-TREJO, F. J.; BARBOSA, H. A.; LAKSHMI KUMAR, T. V. Validating CHIRPS-based satellite precipitation estimates in Northeast Brazil. Journal of Arid Environments, Londres, v. 139, p. 26-40, 2017. https://doi.org/10.1016/j.jaridenv.2016.12.009

PELLEGATTI, C. H. G. Avaliação espaço-temporal da precipitação no perfil da Baixada Santista Vertentes Oceânicas - Rebordo Interiorano da escarpa da Serra do Mar - SP. Dissertação (Mestrado em Geografia Física) - Departamento de Geografia, Universidade de São Paulo. 2007. 128 p.

QGIS DEVELOPMENT TEAM. QGIS Geographic Information System. Open Source Geospatial Foundation. URL http://qgis.osgeo.org. 2009.

QUEIROZ, J. E. R. DE; GOMES, H. M. Introdução ao processamento Digital de Imagens. Revista RITA, Porto Alegre, v. 8, n. 1, p. 11-42, 2001.

R DEVELOPMENT CORE TEAM. R: A language and environment for statistical computing. Vienna, Austria: R Foundation for Statistical Computing. ISBN 3-900051-07-0, 2012.

SANTIAGO, D. B.; GOMES, H. B. Estudo de Ilhas de Calor no Município de Maceió/AL usando Dados Orbitais do Landsat 5. Revista Brasileira de Geografia Física, Recife, v. 09, n. 03, p. 793-803, 2016. https://doi.org/10.5935/1984-2295.20160053

SCHIMDT, P. \& MORRISON, T. H. Watershed management in an urban setting: process, scale and administration, Land Use Policy, Adelaide, v. 29, p. 45-52, 2012.

https://doi.org/10.1016/j.landusepol.2011.05.003

SILVA, J. P; CANEPARO, S. C.; PAULA, E. V. Análise comparativa de dois métodos para obtenção da temperatura de superfície do aglomerado urbano da Região Metropolitana de Curitiba a partir do sensor TM/Landsat-5, Revista Brasileira de Climatologia, Curitiba, v. 14, jan/jul., 2014. https://doi.org/10.5380/abclima.v14i1.36355

TUCKER, C. J. Red and photographic infrared linear combinations for monitoring vegetation. Remote Sensing Environment, Toronto, v. 8, n. 2, p. 127-150, 1979. https://doi.org/10.1016/0034-4257(79)90013-0

UNITED STATED GEOLOGICAL SURVEY (USGS). Using the USGS Landsat 8 Product. Disponível em: < https://Landsat.usgs.gov/using-usgs-Landsat-8-product >. Acessado em 22 fev. 2018.

WILLIS, K. S. Remote sensing change detection for ecological monitoring in United States protected areas.

Biological Conservation, Montpellier, v. 182, p. 233-242, 2015. https://doi.org/10.1016/j.biocon.2014.12.006

WU, D.; ZHAO, X.; LIANG, S.; ZHOU, T.; HUANG, K.; TANG, B.; ZHAO, W. Time-lag effects of global vegetation responses to climate change. Global Change Biology, Illinois, v. 21, n.9, p. 3520-3531, 2015. https://doi.org/10.1111/gcb.12945 